\title{
POSITIVE INTERACTION BETWEEN THE NATIVE MACROALGAE Sargassum SP. AND THE EXOTIC BIVALVE Isognomon bicolor?*
}

\author{
María Soledad López and Ricardo Coutinho \\ Instituto de Estudos do Mar Almirante Paulo \\ Divisão de Bioincrustação, Departamento de Oceanografia. Moreira. \\ (Rua Kioto 253, Praia dos Anjos, Arraial do Cabo, RJ, Brasil) \\ Universidade Federal do Rio de Janeiro \\ Programa de Pós-graduação em Ecologia \\ (Av. Brigadeiro Trompowsky, s/nº . Ilha do Fundão, RJ. Brasil)
}

\begin{abstract}
Biological invasions are one of the most alarming causes of ecosystem changes (CARLTON, 1987; CROOKS, 2002) and economic losses (PIMENTEL et al., 2000). Exotic species are capable of changing the structure, organization and function of the invaded ecosystems (SHEA; CHESSON, 2002). Nowadays, researchers are especially interested in evaluating the negative impact of invaders on native communities (RUIZ et al., 1999; MILLER et al., 2002), identifying the factors that may create resistance or facilitate the introduction of exotic species. Most of the studies have focussed on negative interactions such as competition and predation (DIEDERICH, 2006; GROSHOLZ et al., 2000); however, positive interactions between exotic and native species have recently been registered in many marine systems (CROOKS, 2002; RODRÍGUEZ, 2006; RUESINK, 2007). Positive interactions potentially enhance the establishment and the range of distribution of the exotic species or increase their abundance until they become (until they become?) invaders. Non-indigenous species have been reported on Brazilian coasts and have become a subject of great concern (DA SILVA; SOUZA, 2004). The purseoyster Isognomon bicolor (C.B. Adams 1845) (Bivalvia: Isognomonidae) is a bivalve originally distributed in the Caribbean region that has been identified as an exotic species on Brazilian shores, from Rio Grande do Norte to Santa Catarina states. On rocky shores in the north of Rio de Janeiro state, $I$. bicolor has became an important component on the mid-shore level (DOMANESCHI; MARTINS, 2002). Also, at the intertidal zone of some wave-protected rocky shores, the macroalgae Sargassum sp. forms dense beds on the fringe of the infra-littoral level, and numerous individuals of the exotic bivalve have been observed under the macroalgae fronds. These preliminary observations have suggested a positive association between the native macroalgae Sargassum sp. and the exotic bivalve. So, in this study we tested
\end{abstract}

(*) Paper presented at the $2^{\text {nd }}$ Brazilian Congress of Marine Biology, on 24-28 May. Búzios, RJ, Brazil. 2009. the hypothesis that canopies of Sargassum sp. have a positive effect on the abundance of I. bicolor. To test this: (1) we assessed the percentage cover of the dominant sessile organisms on low intertidal shores for two years and (2) we compared the abundance of $I$. bicolor between areas with manipulation of the Sargassum sp. canopy (natural canopy and canopy removal). The study was conducted on the intertidal rocky shore of the Ilha dos Porcos in the Cabo Frio upwelling region on the Southeastern Brazilian coast $\left(22^{\circ} 44 \mathrm{~S} ; 42^{\circ} 00^{\prime \prime} \mathrm{W}\right)$. This shore, located in a bay and protected from the prevailing NE winds, is considered to have low exposure to wave action. To describe the temporal variation of sessile organisms and to seek a temporal association pattern between Sargassum sp. and I. bicolor abundances, we estimated the percentage cover of the dominant organisms and bare substrate using ten $20 \times 20 \mathrm{~cm}$ quadrants, placed randomly over $35 \mathrm{~m}$ on each shore level. We carried out two samplings in each season of 2005 and one sampling each in the summer, autumn and spring of 2006. Percentage cover was assessed using the pointcontact technique (30 random intersections within the 100-point grid), similar to that used by Foster et al. (1991). To test the interaction between Sargassum sp. and I. bicolor, we compared the percentage cover of the exotic bivalve and other understory organisms in plots with different coverage of Sargassum sp. canopy. Six $25 \times 25 \mathrm{~cm}$ plots were placed in the intertidal zone at low shore level. In three plots, the fronds of the macroalgae were experimentally removed (treatment) and the other three plots were not manipulated (control). The experiment began on March 3, 2006 (day 1), and the percentage cover of the sessile organisms was monitored on seven dates over a period of 29 days. We compared the percentage cover between the treated and control plots with a Student's $t$-test after arcsine data transformation.

The cover of Sargassum sp. varied seasonally, increasing in summer (by more than $40 \%$ and 30\% in 2005 and 2006, respectively) and dropping to less than $10 \%$ of cover in the winter (Fig. 1). Also, the coverage of the exotic bivalve was higher in the 
summer of the two sampling years, being of $11 \%$ and $20 \%$ in 2005 and 2006, respectively. The cover of $I$. bicolor dropped to less than 5\% in autumn, winter and spring (in both years). The cover of the articulated calcareous algae showed an opposite pattern to that of the temporal variation of Sargassum sp and I. bicolor. These algae were scarce (less than $10 \%$ of cover) in summer and increased their coverage three-fold in winter (Fig. 1). In the experimental plots where the Sargassum sp. canopy had been removed (treatment), the percentage cover of I. bicolor dropped from $24 \%$ to $1.1 \%$ in the period from the beginning to the end of the experiment (Fig. 2). On the first and second days of the experiment, the cover of I. bicolor was not different when the control and treatment plots were compared (Day 1: $t=1.15 ; \mathrm{df}=4 ; \mathrm{p}=0.15$ and Day 2: $t=1.52 ; \mathrm{df}=4 ; \mathrm{p}=0.20$ ). After that, the cover of $I$. bicolor tended to be lower in the treatment than in the control plots but the differences were statistically significant only on day $6(t=4.58 ; \mathrm{df}=4 ; \mathrm{p}=0.01)$ and day $7(t=2.90 ; \mathrm{df}=4 ; \mathrm{p}=0.04)$. At the end of the study (day 29), the percentage cover in the control plots was seven times higher than in the treatment plots and this difference was almost significant $(t=2.76 ; \quad d f=4$; $\mathrm{p}=0.05$ ). The cover percentages of the Sargassum $\mathrm{sp}$. apressorium and the barnacle Megabalanus sp. were not different in the control and the treatment plots throughout the experiment (test $t$ : $\mathrm{p}>0.05$; Fig. 2). The articulate calcareous algae coverage was similar in both the manipulated and un-manipulated plots with an increase (from $\sim 3 \%$ to $\sim 14 \%$ ) by the end of the experiment. The percentage cover of the secondary stratum, created by Sargassum sp. fronds, decreased over time being $35 \%$ lower at the end of the experiment (Fig. 2).

Our study focused on a little researched aspect of the biological invasions, the positive interaction between native and exotic species. The results of our observational approach indicated a positive temporal association between the presence of the native macroalgae Sargassum sp. and the abundance of the exotic bivalve I. bicolor. We corroborated this result in our experimental assessment because we observed a diminution in the cover of $I$. bicolor when the Sargassum sp. canopy was removed while the cover of the barnacle Megabalanus spp. did not change. We observed a seasonal pattern in the cover of articulated calcareous algae negatively associated with Sargassum sp. Other studies have also observed a dominance of the articulate calcareous algae after the removal of the secondary stratum formed by a macroalgae canopy of different species (BULLERI et al., 2002; LILLEY; SCHIEL, 2006). Physical changes under fronds, such as low illumination, low temperature and reduced water flow, the reduction of the abrasion caused by fronds, or by the interaction of all these factors, might explain this pattern (IRVIN; CONNELL, 2006; RUSSELL, 2007). Although differences in the bivalve cover between treatment and control plots were evident throughout the experiment, we also observed a decrease of the bivalves in the un-manipulated plots, mainly towards the end of the experiment. That may have been because of the simultaneous reduction of the macroalgae canopy (secondary stratum) observed in the control plots. The reduction in the cover of Sargassum sp. is a natural process because of the macroalgal life cycle related to the seasonal upwelling in the region (GUIMARAES et al., 2008). In general, at the end of the summer (when this study was carried out) Sargassum sp. loses its blades progressively until the whole frond of the algae disappears leaving the apressorium fastened to the substratum (pers. obs.). We propose two possible explanations for the association between the macroalgae and I. bicolor: (a) the canopy of Sargassum sp. facilitates I. bicolor larval settlement and/or enhances the possibility of the survival of recruits and adults, due to the protection it offers against predators or (b) the physical conditions created inside the micro-habitat formed by macroalgae fronds diminish thermal stress and desiccation. However, protection against desiccation and heat is not the most plausible explanation because I. bicolor commonly dominates higher shore levels (the mid zone) than infralitoral fringe of the intertidal. These topics deserve future experimental studies with more spatial and temporal replication.

The positive association between I. bicolor and native species could facilitate the expansion of the bivalve's distribution to habitats less exploited by this exotic species. A prior study demonstrated that $I$. bicolor is not a pioneering species in substratum colonization because the presence of other species such as barnacles and filamentous algae are essential for its settlement (ROCHA, 2002). Moreno (1995) observed that the recruitment of the bivalve Choromytilus chorus inside filamentous macroalgae reduced predation by gastropods, allowing the prey to reach the escape size of predation. While some studies have shown that macroalgae could benefit understory assemblages by reducing predator density or predation efficiency (PETERSON, 1982), other studies have found stronger predator effect under the macroalgal fronds (BERTNESS et al., 1999). We did not observe any predation events or signs of predation (holes, broken shells) that would suggest bivalve consumption by benthic predators. In our study the whole individual of $I$. bicolor was detached from the substratum and perhaps the macroalgal fronds reduced the field of vision of non-benthic predators, such as fish and birds, that prey from above. An experiment of predator exclusion carried out on the same shore showed intense predation on bivalves by non-benthic predators (unpublished data). These predators have greater 
mobility and they take less time than benthic predators to manipulate this prey, which would explain the removal of whole bivalves in plots without a canopy. It is possible that the pattern of Sargassum sp. seasonal variation explains the decrease of I. bicolor cover at low shore levels and the infra-littoral fringe in the seasons when the macroalgae is absent (autumn, winter and the beginning of the spring). At this point the synchrony of the development of Sargassum sp. beds with the I. bicolor larval supply is essential. The inter-annual consistence of our results should be evaluated by long-term monitoring. Different species of Sargassum create dense beds on rocky shores on the coast of southeastern Brazilian (SZÉCHY; PAULA, 2000). In the sub-littoral zone of the Ilha de Queimadas of the coast of São Paulo State, a qualitative study has also registered the presence of $I$. bicolor as part of the fauna associated with Sargassum sp. (JACOBUCCI et al., 2006). Our study underlines the importance of investigating the association between this macroalga and I. bicolor in other areas of the Brazilian coast, where the two species occur together, since the positive interaction demonstrated by this study may increase the vulnerability of environments which have not yet been invaded by $I$. bicolor.



Fig. 1. Percentage cover of the three dominant organisms (average $\pm \mathrm{SE} ; \mathrm{n}=10$ ) on the rocky shore of Ilha dos Porcos in 2005 and 2006. S= Summer; A= Autumn; W= Winter; SP= Spring. The numbers indicate the times of the two sampling made in each season during 2005.

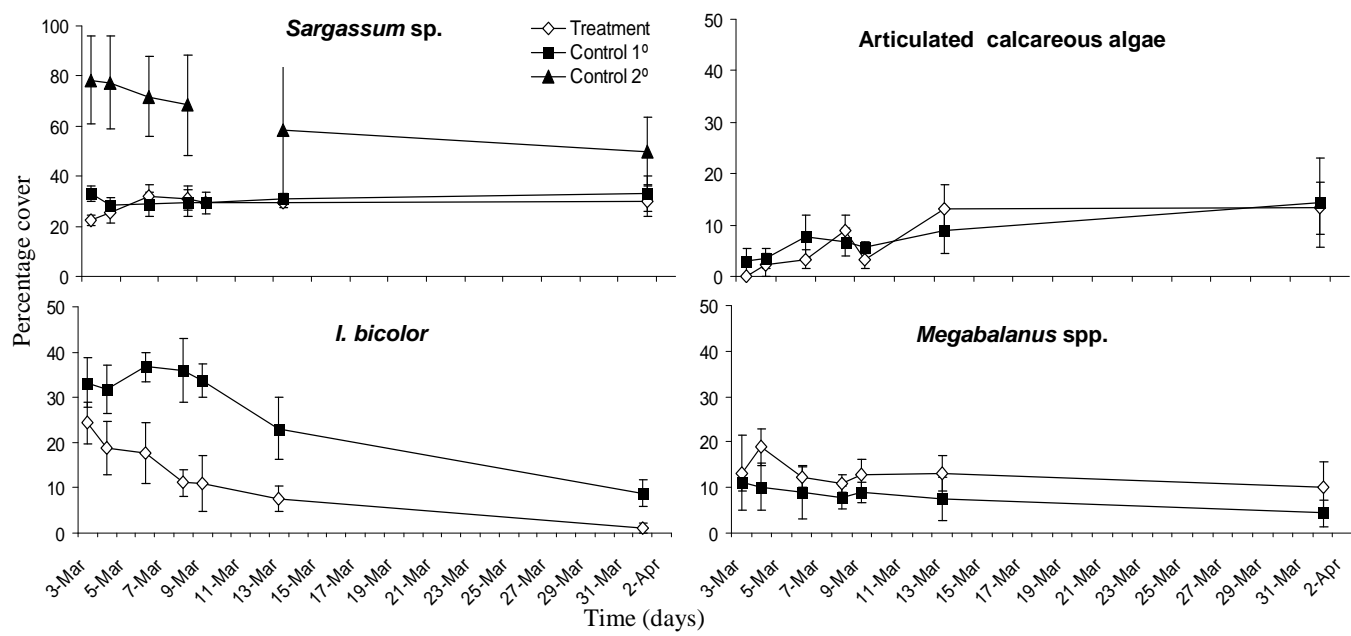

Fig. 2. Temporal variation of the percentage cover (average \pm SE; $n=3$ ) of four sessile organisms registered in treatment (without macroalgae fronds) and control plots (with natural coverage of macroalgae canopies) in the intertidal zone of the rocky shore of the Ilha dos Porcos. Control 1 is the cover of apressorium (primary stratum), and Control 2 is the cover of fronds (secondary stratum). Note the differences of scale on the axes. 


\section{ACKNOWLEDGEMENTS}

Many thanks to all the team of the Divisão de Bioincrustação (IEAPM) that helped in our field work. This research project was supported by the Coordenação de Aperfeiçoamento em Pessoal de Nível Superior-CAPES' doctoral fellowship granted to M.S. López and grants made by the Fundação de Amparo à Pesquisa do Rio de Janeiro-FAPERJ and the Conselho Nacional de Desenvolvimento Científico e Tecnológico-CNPq to R. Coutinho.

\section{REFERENCES}

BERTNESS, M.D.; LEONARD, G.H.; LEVINE, J.M.; et al Testing the relative contribution of positive and negative interactions in rocky intertidal communities. Ecology, v. 80, n. 8, p. 2711-2726, 1999.

BULLERI, F.; BENEDETTI-CECCHI, L.; ACUNTO, S.; et al. The influence of canopy algae on vertical patterns of distribution of low-shore assemblages on rocky coasts in the northwest Mediterranean. J. exp. mar. Biol. Ecol., v. 267, p. 89-106, 2002.

CARLTON, J.T. Patterns of transoceanic marine biological invasions in the Pacific Ocean. Bull. mar Sci, v. 41, n. 2 , p. 452-465, 1987.

CROOKS, J. A. Characterizing ecosystem-level consequences of biological invasions: the role of ecosystem engineers. Oikos, v. 97, p. 153-165, 2002.

DA SILVA, J. S. V.; SOUZA, R. C. Água de lastro e bioinvasão. Rio de Janeiro: Ed. Interciência, 2004.

DIEDERICH, S. High survival and growth rates of introduced Pacific oysters may cause restrictions on habitat use by native mussels in the Wadden Sea. J. expl mar. Biol. Ecol., v. 328, n. 2, p. 211-227, 2006.

DOMANESCHI, O.; MARTINS, C.M. Isognomon bicolor (C.B.Adams) (Bivalvia, Isognomonidae): primeiro registro para o Brasil, redescrição da espécie e considerações sobre a ocorrência e distribuição de Isognomon na costa brasileira, Rev. Bras. Zool., v. 19, n. 2, p. 611-627, 2002

FOSTER, M. S.; HARROLD, C.; HARDIN, D. D. Point vs. photo quadrant estimates of the cover of sessile marine organisms, J. expl mar. Biol. Ecol., v. 146, p. 193-203, 1991.

GROSHOLZ, E. D.; RUIZ, G. M.; DEAN, C. A.: et al. The impacts of a nonindigenous marine predator in a California Bay, Ecology, v. 81, n. 5, p. 1206-1224, 2000.

GUIMARÃES, M. A.; GONÇALVES, J. E. A.; LOURENÇO, S. O.; COUTINHO, R. Sensivity analyses of population biomass dynamics for Ulva sp. and Sargassum furcatum at the Cabo Frio upwelling region of Brazil. J. Biol. Syst., v. 16, n. 4, p. 579-596, 2008

IRVING, A. D.; CONNELL, S. D. Physical disturbance by kelp abrades erect algae from the understorey. Mar. Ecol. Progr. Ser., v. 324, p. 127-137, 2006.
JACOBUCCI, G. B.; GÜTH, A. Z; TURRA, A.; et al. Levantamento de Mollusca, Crustacea e Echinodermata associados a Sargassum spp. na Ilha da Queimada Pequena, Estação Ecológica dos Tupiniquins, litoral sul do Estado de São Paulo, Brasil. Biota Neotrop., v. 6, n. 2, http://www.biotaneotropica.org.br/v6n2/pt/abstractinvent ory+bn02706022006, 2006.

LILLEY, S. A.; SCHIEL, D. R. Community effects following the deletion of a habitat-forming alga from rocky marine shores. Oecologia, v.148, p. 672-681, 2006.

MILLER, T.E.; KNEITEL, J.M.; BURNS, J.H. Effect of community structure on invasion success and rate. Ecology, v. 83, n. 4, p. 898-905, 2002.

MORENO, C. A. Macroalgae as a refuge from predation for recruits of the mussel Choromytilus chorus (Molina, 1782) in Southern Chile. J. expl mar. Biol. Ecol., v. 191, p. 181-193, 1995.

PETERSON, C. H. Clam predation by whelks (Busycon spp.): experimental tests of the importance of prey size, prey density, and seagrass cover. Mar Biol, v. 66, p. 159-170, 1982.

PIMENTEL, D.; LACH, L.; ZUNIGA, R.; MORRISON, D. Environmental and economic costs of nonindigenous species in the United States. Bioscience, v. 50, n.1, p. 53$65,2000$.

ROCHA, F. M. Recrutamento e sucessão de uma comunidade bentônica de mesolitoral dominada pela espécie invasora Isognomon bicolor (Bivalvia: Isognomidae) C.B. Adams, 1748 em dois costões rochosos submetidos a diferentes condições de batimento de ondas. 2002. 82 p. Dissertação (Mestrado) Instituto de Biologia, Universidade Federal do Rio de Janeiro, RJ, 2002.

RODRIGUEZ, L. F. Can invasive species facilitate native species? Evidence of how, when, and why these impacts occur. Biol. Invas., v. 8, p. 927-939, 2006.

RUESINK, JL. Biotic resistance and facilitation of a nonnative oyster on rocky shores, Mar. Ecol. Progr. Ser., v. 331, p. 1-9, 2007.

RUIZ, G.M.; FOFONOFF, P.; HINES, A.H.; GROSHOLZ, E.D. Non-indigenous species as stressors in estuarine and marine communities: assessing impacts and interactions. Limnol. Oceanogr., v. 44, p. 950-972, 1999.

RUSSELL, B.D. Effects of canopy-mediated abrasion and water flow on the early colonization of turf-forming algae. Mar. Fresh. Res., v. 58, n.7, p. 657-665, 2007.

SHEA, K.; CHESSON, P. Community ecology theory as a framework for biological invasions. Trends Ecol. Evolution., v. 17, n. 4, p. 170-176, 2002.

SZÉCHY, M. T. M.; PAULA, E. J. Padrões estruturais quantitativos de bancos de Sargassum C. Agardh (Phaeophyta, Fucales) do litoral dos estados do Rio de Janeiro e São Paulo, Brasil. Rev. Bras.Bot., v. 23, p. 121-132, 2000 .

(Manuscript received 04 June 2009; revised 10 November 2009; accepted 02 March 2010) 